\title{
Identification of Species Causing Cutaneous Leishmaniasis by PCR in Chahbahar, Iran
}

Hosein Soleimanpoor (MSc)

Department of Parasitology, Zabol

University of Medical Sciences, Zabol, Iran

Mansour Dabirzadeh (PhD)

Department of Parasitology and Mycology, Faculty of Medicine, Zabol University of Medical Sciences, Zabol, Iran

Bahman Fooladi (MSc)

Department of Parasitology, Zabol

University of Medical Sciences, Zabol, Iran

Corresponding Author: Mansour

Dabirzadeh

Email:

mdabirzadeh20002000@yahool.com

Tel: +989131002177

Address: Faculty of Medicine, Zabol

University of Medical Sciences, Zabol, Iran

Received : 02 Dec 2014

Revised: 01 Feb 2015

Accepted: 04 Feb 2015
ABSTRACT

Background and Objective: Chabahar is in Southern Iran located near the IranPakistan border. Since leishmaniasis is an emerging disease in this region, this study aimed to diagnose the disease and identify different species of Leishmania parasite in the patients referred to the central laboratory.

Methods: This descriptive cross-sectional study was conducted in 2011-2012 on patients referred to the central laboratory in the city of Chabahar. The sampling of lesions, slide preparation, culture and PCR specific for kinetoplast DNA (kDNA), extracted from the media and slides, were performed. The data collected by a questionnaire were analyzed by the SPSS software.

Results: The resulted bands from the 40 tested cutaneous leishmaniasis isolates were compared with the standard strains of Leishmania tropica, L. infantum and L. major. All 48 investigated bands were in the $620 \mathrm{bp}$ region, which is related to $\mathrm{L}$. major.

Conclusion: Since PCR has high sensitivity and specificity, it is recommended to use kDNA (present in a unique organelle called kinetoplast) for the routine diagnosis and treatment of the disease.

Keywords: Leishmaniasis, Cutaneous, Polymerase Chain Reaction, Iran. 


\section{INTRODUCTION}

Leishmaniasis is caused by protozoan parasites of the genus Leishmania. Its vector is female sandflies from the Phlebotomus genus. From the epidemiologic perspective, the causes of cutaneous leishmaniasis or leishmaniasis in Iran are Leishmania major, L. tropica and less likely $L$. infantume $(1,2)$.

Cutaneous leishmaniasis is one of the most important public health problems in many parts of Iran (3). Typically, diagnosis of cutaneous leishmaniasis is based on clinical symptoms found in patients and its confirmation by parasitological methods (4).

Although the accurate identification of species are of great epidemiological and clinical importance, it is not yet possible to do so due to the similarity of morphological and clinical manifestations $(1,3)$. Sometimes the phenotype does not represent the genotype and lesions caused by L.tropica along with Crithidia would cause L. major-like moist wounds (2). Lesions also manifest in multiple atypical forms as demonstrated by a study in Isfahan, clinical leishmaniasis were observed in $7.1 \%$ of cases in unusual shapes $(1,3)$. Thus, the distinction between species requires molecular techniques, enzyme electrophoresis, DNA hybridization probes and polymerase chain reaction (PCR) (5). The high sensitivity and specificity are some advantages of DNA replicationdependent methods (1). kDNA have multiple copies of minicircles which makes it a suitable target for diagnosis (6).

Nowadays, due to the advances in molecular methods including numerous techniques, different molecular markers have been developed to assess and distinguish different species of Leishmania $(7,8)$. So far, ribosomal ssuRNA (9), internal transcribed spacers (10), tubulin gene (11), gp63 gene (12), microsatellite DNA (13), extrachromosomal DNA and kDNA minicircles (14) have been used as target genes for the detection of Leishmania. Therefore, shizodeme analysis and kDNA were used in this study to determine the species and evaluate the population of Leishmania. The main aim of this study was to determine the species causing cutaneous leishmaniasis using the PCR method in the city of Chabahar.

\section{MATERIAL AND METHODS}

This was a descriptive and cross sectional study on 48 patients with cutaneous leishmaniasis who were referred to the central laboratory of Chabahar during 2011-2012. Data were collected from patients with cutaneous leishmaniasis through a prepared questionnaire. This study was conducted to determine the cutaneous leishmaniasis causing species in the city of Chabahar. The samples were obtained from the lesions of the patients with cutaneous leishmaniasis referred to the central laboratory during 2011-2012. Data were gathered using a questionnaire.

First, the patients' lesions were disinfected with ethanol and the help of scalpel or vaccinostyle, steriled on flame. After cooling, the samples were obtained from the edge and border of the swollen wounds, in depth and from the floor of the wound. The resulting serosity from each isolate was transferred onto N.N.N medium. In addition, two microscopic slides were prepared from thin layer spreads of some of the lesion samples from each patient. The obtained samples were kept in special flasks containing ice (Icebag) with temperature of $4-6{ }^{\circ} \mathrm{C}$ during transportation.

DNA extraction was done using kits in order to obtain sufficient amount of pure DNA with no contamination. At this stage, amastigotes were collected from the slides and the standard medium. High Pure PCR Template Preparation kit (Roche co.) was used for DNA extraction. The prepared slides from the patients were also used for DNA extraction. The steps were performed according to the kit manufacturer's protocol.

After DNA extraction from the obtained samples based on the above procedures, PCR was done for DNA amplification and determination of cutaneous leishmaniasis causing specie using Leishmania PCR determination and detection Kit (CinnaGen Co.) in the city of Chabahar. In order to identify the Leishmania species causing cutaneous leishmaniasis, specific genome of specie and specific kDNA markers were used. The pair of primers used in this experiment included an upstream 5' TCG CAG AAC GCC 
CCT ACC 3' and downstream 5' AGG GGT TGG TGT AAA ATA GGC 3' primer, which were used to find the Leishmania kDNA sequence (14). The thermocycler temperature program included: an initial denaturation cycle at $95{ }^{\circ} \mathrm{C}$ for 3 minutes, then 34 cycles of primers annealing at $63{ }^{\circ} \mathrm{C}$ for 30 seconds, elongation at $72{ }^{\circ} \mathrm{C}$ for 60 seconds and secondary denaturation at $93{ }^{\circ} \mathrm{C}$ for 40 seconds and finally, a cycle at $72{ }^{\circ} \mathrm{C}$ for 5 minutes. After PCR amplification of kDNA of the samples from the patients with cutaneous leishmaniasis, the PCR products were electrophoresed on $1 \%$ agarose gel along with the standard strains of L. tropica (MHOM / SU / 79 / K27), L. major (MHON / IR75 / ER), L. infantum (MHON / IR03 / MASH878) and negative control ( distilled water). The profiles or the pattern of resulted bands was recorded using a gel documentation system (Gel Doc.) and identified by comparing the size of the bands related to the patients' samples with the marker bands (Figure 1).

At this stage, $1 \mathrm{X}$ Tris/Borate/EDTA and 1\% agarose gel were prepared. After staining with GelRed, the PCR products were loaded onto the horizontal electrophoresis apparatus and next to the $1000 \mathrm{bp}$ DNA ladder. The results were studied and imaging was done using a transilluminator and Gel Doc.

\section{RESULTS}

In this study, $60.4 \%$ of the infected individuals were male and the rest were female. The $X^{2}$ test showed no significant difference between the two genders in terms of parasitic infection. The demographic characteristics of the participants are shown in Table 1. Table 2 represents the frequency of ulcers in different parts of the body. The results showed that the purified DNA of all 48 patients tested had the $620 \mathrm{bp}$ band, which is associated with L. major.

Table 1- Demographic characteristics of the subjects

\begin{tabular}{|c|c|c|c|}
\hline Percentage & Number & & \\
\hline 39.6 & 19 & Under 10 years & \multirow{5}{*}{ Age } \\
\hline 29.1 & 14 & 11-20 years & \\
\hline 16.6 & 8 & 21-30 years & \\
\hline 14.7 & 7 & Over 30 years & \\
\hline 60.4 & 29 & male & \\
\hline 39.6 & 19 & female & Gender \\
\hline 4.1 & 2 & High & \multirow{4}{*}{$\begin{array}{c}\text { Socioeconomic } \\
\text { status }\end{array}$} \\
\hline 8.2 & 4 & Upper Middle & \\
\hline 52.2 & 25 & Middle & \\
\hline 35.5 & 17 & Lower Middle & \\
\hline 52.1 & 25 & Chahbahar & \multirow{5}{*}{$\begin{array}{c}\text { Residential } \\
\text { site }\end{array}$} \\
\hline 8.2 & 4 & Dashtyari & \\
\hline 6.3 & 3 & Tis & \\
\hline 8.2 & 4 & Plan & \\
\hline 25.2 & 12 & Other sites & \\
\hline
\end{tabular}

Table 2- Frequency of ulcers in patients with cutaneous leishmaniasis in terms of the wound site

\begin{tabular}{cccccccccc}
\hline Total & $\begin{array}{c}\text { Hand, } \\
\text { foot, } \\
\text { trunk }\end{array}$ & $\begin{array}{c}\text { Foot } \\
\text { and } \\
\text { face }\end{array}$ & $\begin{array}{c}\text { Hand } \\
\text { and } \\
\text { foot }\end{array}$ & $\begin{array}{c}\text { Foot } \\
\text { and } \\
\text { body }\end{array}$ & $\begin{array}{c}\text { Hand } \\
\text { and } \\
\text { face }\end{array}$ & face & feet & hands & $\begin{array}{c}\text { Ulcer } \\
\text { site }\end{array}$ \\
\hline 48 & 1 & 2 & 2 & 1 & 1 & 10 & 18 & 13 & Number \\
100 & 2.2 & 4.4 & 4.4 & 2.2 & 2.2 & 20.2 & 37.5 & 27.1 & Percentage \\
\hline
\end{tabular}


Figure 1- PCR products on (1\%) gel electrophoresis, imaged by the transilluminator

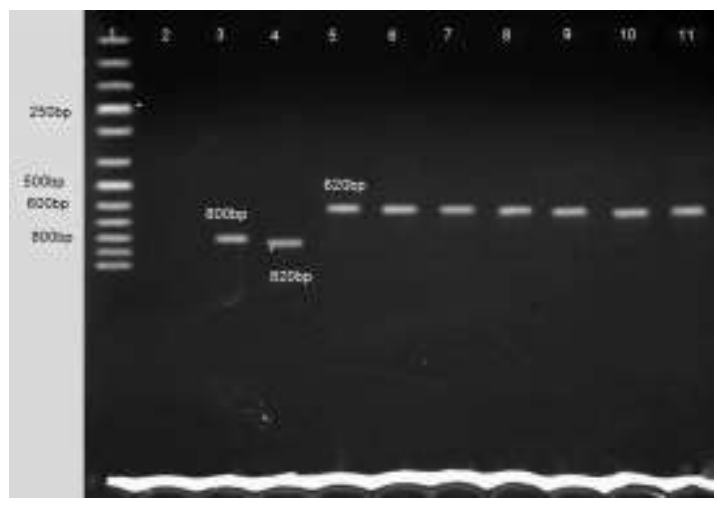

Column 1: DNA Ladder \& Marker (1000bp), Column 2: Negative control (distilled water), Column 3: L. tropica control MHON/IR03/MASH878 (800bp), Column 4: L. infantum control MCAN/IR07/MOHEB-GH (820bp), Column 5: L. major control MHON/IR75/ER (620bp), Column 6-11: PCR products related to the patients' samples (620bp)

\section{DISCUSSION}

Several studies have been conducted by researchers in different parts of Iran. Similar to the present study, the studies in Mirjaveh and Damghan $(15,16)$ have reported L. major as the cause of cutaneous leishmaniasis. However, the studies in endemic areas of Iran including Shush, Shiraz, Sabzevar and Mashhad found both species of $L$. major and $L$. tropica as the causes of cutaneous leishmaniasis $(6,17-19)$.

A pair of specific primers against kDNA was used in this study. The parasite's kDNA and circular DNA were good targets for molecular diagnostic studies and identification of the species due to having thousands of variable and conserved copies. On the other hand, this region has many taxonomic applications due to its high number of copies and repetitive sequences in the parasite genome (20). Similar to some studies, the present study used kDNA (present in a unique organelle called kinetoplast) that is both specific and highly sensitive for diagnosis.

In the present study, only L. major was found as the cause of cutaneous leishmaniasis. The prevalence of ulcers in the extremities such as hands and feet was higher, which is consistent with a study in Damghan (16).

Although many patients stated that they have never left the villages of Chabahar, the disease was still present in villages outside Chabahar. This indicates the presence of disease reservoir and potential vectors, as well as the increasing trend of the disease in this region. Considering the evolutionary process of the parasite and different times of the disease incidence in this
The statistical analysis also showed that the highest prevalence of infection was related to both genders in the individuals under 10 years of age $(39.6 \%)$ and the lowest prevalence was observed in the age group of over 31-40 years $(2.1 \%)$, while it was similar or evenly distributed in the rest of the age groups. The highest rate of infection was related to the patients less than 10 years of age, while it decreased in older age groups.

Other studies have also reported that the incidence of rural cutaneous leishmaniasis was higher in children in comparison to adults. In agreement with our findings, Sharifi and Zamani study on the epidemiology of cutaneous leishmaniasis in Southern areas of the city Baft reported the highest prevalence of the disease in the age group of 10-11 years (23).

The highest infection rates were observed in the participants with low or average socioeconomic status, living in poor houses. In the study of Ebadi et al., 93\% of the patients were living in poor houses and areas with low socioeconomic status. The development of urbanization, city expansion and construction, high load of construction waste and unsanitary disposal of waste may be related to the risk of outbreak and spread of disease (24).

Such diseases are thought to be controlled or eradicated in the developed countries that have high levels of health facilities. The city of Chabahar and its surroundings still have wastelands that seem to be the living area of rodents that can act as reservoirs of the disease. 
In this study, the extent of the area and numerous migrations to this area as a free zone should be considered. The geographical factors such as climate, agricultural development, development of cities and commerce are associated with the spread of the disease in this region. On the other hand, these also allow the possibility of developing new hybrids that could cause further problems for the treatment and prevention of this disease. Considering the short distance with Pakistan, it is expected to find the hybrid strains that have the pathological features of any specie in Iran and Pakistan. The hybrid parasites have been reported in Saudi Arabia and Ecuador $(26,25)$.

In this study, DNA was obtained from promastigotes, the culture medium and slides. There is an issue with diagnosis of Leishmania and the role of each parasite in pathogenicity in humans. It must be said that the selective cell culture eliminates a specie or strain. This issue has been demonstrated in a study conducted in Bolivia (27).

\section{CONCLUSION}

Cutaneous leishmaniasis is an important health problem in the province of Chabahar and planning for controlling this disease should

\section{REFERENCES}

1. Dabirzadeh M, Mirmohammad Sadeghi H, Baghaie M, Hejazi H. Genetic polymorphism of Leishmania major in two hyper endemic regions of Iran revealed by PPIP-PCR and ITS-RFLP. Arch Iran Med. 2012; 15(3): 151-6. doi: 012153/AIM.009.

2. Spotin A, Rouhani S, Parvizi P. The associations of Leishmania major and Leishmania tropica aspect by focusing their morphological and molecular features on clinical appearances in Khuzestan pronince,Iran. BioMed Research International. 2014; Article ID913510: 13 pages.

3. Hejazi H, Mirmohammad sadeghi H, Dabirzadeh M, Nilforoushzadeh MA, Baghaei M. Atypical clinical forms of zoonotic cutaneous leishmaniasis due to Lishmania major in Isfahan, Iran. journal of Isfahan Medical School (I.U.M.S). 2007; 25(Suppl 8): 43-49.

4. Baghaei A, Jasbi E, Akhoundi M, Mirzaei H, Dehnam O. Microscopic and molecular detection of Leishmania species among suspected patients of cutaneous leishmaniasis using ITS-r DNA in Fars province. J Shahid Sadoughi Univ Med Sci. 2012; 20(4): 464-73.

5. Pagheh AS, Fakhar M, Mesgarian F, Gholami S, Badiee F. Detection and Identification of Causative Agent of CutaneousLeishmaniasis Using Specific PCR. J Mazand Univ Med Sci. 2012; 22(Supple 1): 8592.[Persian] be taken into consideration. Some efective measures should be taken for prevention of the disease by considering the side effects, cost of treatment and prevention of emotional and psychological damages caused by the disease. Moreover, using lace, mosquito nets and insect repellent creams will be effective in preventing the disease. It is suggested to conduct a study on the entire region to identify the cause of cutaneous leishmaniasis in this region. Furthermore, some epidemiological studies are recommended for identification of the exact type of rodent (as the disease reservoir) and specie of sandflies (as vectors) in this region, as well as molecular studies to identify the parasite vectors and reservoirs.

\section{ACKNOWLEDGMENT}

The authors would like to thank the Department of Research and Technology of Zabol University of Medical Sciences for the financial support. We also would like to thank the Deputy of Health of Chabahr, the Central Laboratory of Chabahar and their staff for their assistance in this study.

\section{CONFLICT OF INTEREST}

All contributing authors declare no conflicts of interest.

6. Abdolmajid F, Ghodratollah SS, Hushang R, Mojtaba $\mathrm{MB}$, Ali MM, Abdolghayoum M. Identification of Leishmania species by kinetoplast DNA-polymerase chain reaction for the first time in Khaf district, Khorasan-eRazavi province, Iran. Trop Parasitol. 2015; 5(1): 50-4. doi: 10.4103/2229-5070.145587.

7. Shirzadi MR, Sharifian J, Zeinalin M, Qarahgozloo F, Pourmozaffari J, Doosti S. Successful in zoonosis control progammes. $1^{\text {st }}$ ed. Tehran: Ministry of Health and Medical Education Publication. 2009.[Persian]

8. Khalili M, Nourollahi-fard SR. Detection and genotyping of cutaneous leishmaniasis species in the southeast of Iran: restriction enzyme analysis (RFLP).Tehran University Medical Journal. 2009; 67(3): 168-172.

9. Van Eys GJ, Schoone GJ, Kroon NC, Ebeling SB. Sequence analysis of small subunit ribosomal RNA genes and its use for detection and identification of Leishmania parasites. Mol Biochem Parasit. 1992; 51(1): 42-133.

10. Eisenberger CL, Jaffe CL. Leishmania: identification of Old World species using a permissively primed intergenic polymorphic polymerase chain reaction. Exp Parasitol. 1999; 91(1): 7-70 . 
11. Luis L, Ramirez A, Aguilar CM, Eresh S, Barker DC, Mendoza Leon A. The genomic fingerprinting of the coding region of the $\beta$ tubulin gene in Leishmania identification. Acta Trop 1998; 69(3): 204-193 .

12. Victoir K, Banuls AL, Arevalo J, Llanos Cuentas A, Hamers R, Noel S, et al. The gp63 gene locus, a targetfor genetic characterization of Leishmania belonging to subgenus Viannia. Parasitology. 1998; 117(1): 1-13.

13. Russell R, Iribar MP, Lambson B, Brewster S, Blackwell JM, Dye C, et al. Intra and inter specific microsatellite variation in the Leishmania subgenus Viannia. Mol Biochem Parasit. 1999; 103(1):71-7.

14. De Bruijn MH, Barker DC. Diagnosis of New World Leishmaniasis: specific detection of species of theLeishmania braziliensis complex by amplification of kinetoplast DNA. Acta Trop. 1992; 52(1): 45-85. PMID:1359760.

15. Fazaeli A, Fouladi B, Hashemi-Shahri SM, Sharifi I. Clinical Features of Cutaneous Leishmaniasis and Direct PCR based.Identification of Parasite Species in A New Focus in Southeast of Iran. Iranian J Publ Health. 2008; 37(3): 44-51.

16. Mohammadi Azni S, Rasi Y, Oshaghi M A, Yaghoubi Ershadi M, Mohebali M, Abaie M, et al. Diagnosis and Characterization of Leishmania Species in Patients and Rodents Giemsa-Stained Slides by PCR-RFLP in Damghan District, Iran. Sci J Hamadan Univ Med Sci. 2011; 17(4): 5-9.

17. Maraghi S, Samarbaf Zadeh A, Sarlak AA, Ghasemian M, Vazirianzadeh B. Identification of Cutaneous Leishmanisis Agents by Nested Polymerase Chain Reaction(Nested-PCR)in Shush City,Khuzestan Province, Iran. Jundishapur J Microbiol. 2013; 6(4): e4866.

18. Mohajeri M, Shamsian S.A, Rezaee A, Hasan poor K, Shakeri MT, Farnoosh Gh, et al. Evaluation of molecular epidemiology of Identification Cutaneous Lieshmaniasis in Sabzevar. Medical Journal of Mashhad university of medical sciences fall. 2010; 53(3): 138-144.

19. Mahmoodi MR, Tavakkol Afshari J, Mohajery M, Shakeri MT, Yazdan panah MJ, Berenji F, et al. Molecular Identification of Leishmania Species Causing Cutaneous Leishmaniasis in Mashhad, Iran. Jundishapur J Microbiol. 2010; 3(4): 195-200.
20. Marcela M. satow, Yamashiro-kanashiiro, Mussya C rocha, Luiza K oyfuso. Applicability of kDNA-PCR for routine diagnosis of american tegumentary leishmaniasis in a tertiary reference hospital. Rev Inst Med Trop Sao Paulo. 2013; 55(6): 393-399. doi: 10.1590/S003646652013000600004.

21. Karamian M, Faroghi Bojd MS, Hemmati M, Alireza Sadatjoo S, Barati DA. Molecular identification of cutaneous leishmaniasis agents in Birjand, Iran. Journal of Birjand University of Medical Sciences. 2013; 20(2): 183-190.

22. Yaghoobi-Ershadi MR, Jafari R, Hanafi-Bojd AA. A new epidemic focus of zoonotic cutaneous leishmaniasis in central Iran. Ann Saudi Med. 2015; 24(2): 98-101.

23. Sharifi I, Zamani F, Aflatoonian MR, Fekri AR. $\underline{A n}$ Epidemic of Cutaneous Leishmaniasis in Baft District in Kerman Province and its Probable Causative Risk Factors. irje 2008, 4(1): 53-58.

24. Ebadi M, Hejazi H. The Epidemiological Study of Cutaneous Leishmaniaisis Situation in the Students of Primary School in Isfahan Borkhar Region. Journal of Kerman University of Medical Sciences. 2003; 10(2): 9298.

25. Ibrahim ME, Smyth AJ, Ali MH, Baker DC, Kharami A. The polymerase chain reaction can reveal the occurrence of naturally mixed infection with Leishmania parasites. Acta Tropica. 1994; 57(4): 327-332.

26. Kelly J M, Law JM, Chapman C J, VanEys GJ, Evance $\mathrm{nD}$ A. Evidence of genetic recombination in Leishmania. Molecular and Biochemical parasitology.1991; 46(2): 253-263.

27. Bastrenta B, Mita N, Buitrago R, Vorgas F, Flores M, Machane M, et al. Human mixed infection of Leishmania spp.and Leishmania-Trypanosoma cruzi in a sub Andean Bolivian area:identification by polymerase chain reaction /hybridization and isoenzyme. Memorias do Instituto Oswaldo Cruz. 2003; 98(2); 255-264. PMID:12764443. 